\title{
Pronouns, Presuppositions, and Semantic Variation
}

\author{
Lisa Matthewson \\ University of British Columbia
}

\section{Introduction}

In this paper I intend to establish that the semantics of third-person pronouns is cross-linguistically variable, and in particular, that not all languages possess thirdperson pronouns which are definite, in the sense of displaying familiarity effects. I will argue for this on the basis of data from St'át'imcets (Lillooet Salish). I will then account for the St'át'imcets data in terms of independently-established differences between St'át'imcets and more familiar languages such as English.

First, some background. In English, third-person pronouns like she, it or they are definite. In Heim's (1982) and Kamp's (1981) frameworks, pronouns are necessarily familiar: they introduce variables which are already present in Dom(F) or the DRS. Many have proposed that pronouns, on at least some of their uses, are disguised definite descriptions; see Cooper (1979), Heim (1990), Neale (1990), von Fintel (1994), Chierchia (1995), Sauerland (2000), among others. And some have claimed that third-person pronouns are in fact definite determiners; see Postal (1966), and more recently Elbourne (2001, 2005), who argues that (1a) has 'an LF almost or precisely identical to' that of (1b) (Elbourne 2005:42).

a. $\quad$ Every man who owns a donkey beats it.

b. Every man who owns a donkey beats the donkey.

According to Elbourne, it has the same semantics as the. The pronoun and the determiner differ merely in that the former involves NP-deletion. ${ }^{1}$

Elbourne's claim that in English, pronouns are definite determiners raises an important cross-linguistic question: in languages which lack definite determiners, what is the semantics of third-person pronouns? Does the pronoun/determiner parallel break down in such languages? Or do we instead find that the semantics of third-person pronouns covaries with that of determiners?

Here I will address these questions by investigating the semantics of

I am very grateful to St'át'imcets consultants Gertrude Ned, Laura Thevarge, Rose Agnes Whitley and the late Beverley Frank. I am also very grateful to Angelika Kratzer, Hotze Rullmann, Philippe, Schlenker, Florian Schwarz, Mark Scott, Raj Singh, Tamina Stephenson, Anna Szabolcsi, Satoshi Tomioka, Martina Wiltschko, and audiences at the University of British Columbia, the University of Victoria, and SALT XVIII for helpful discussion. I am especially grateful to Henry Davis, whose contribution to this research is enormous. Errors are my own. This research is supported by SSHRC grants \#410-2002-1715, \#410-2003-1138, and \#410-2005-0875.

${ }^{1}$ Roberts (2004) argues that pronouns differ from definite descriptions in being subject to extra salience requirements; cf. also Heim's (1982:385-386) Prominence Condition. If this is correct, then pronouns cannot be fully equivalent to definite determiners. However, Roberts still analyzes pronouns as inducing familiarity effects parallel to those of definite descriptions. See footnote 17. 
pronouns in a language which lacks definite determiners, namely St'át'imcets. St'át'imcets lacks any determiners which display familiarity effects (Matthewson 1998, 1999). Strikingly, third-person pronouns in this language display a parallel result: as observed by Davis (2006), third-person pronouns in St'át'imcets also lack familiarity effects. An example is given in (2), which shows that St'át'imcets allows backwards pronominalization in a context in which English normally does not (as seen by the infelicity of the English gloss). ${ }^{2}$

$$
\begin{array}{lll}
\begin{array}{l}
\text { súcwt-en-as } \\
\text { recognize-DIR-3ERG }
\end{array} & \text { DET=kúkwpi7=a } & \text { pro }_{E R G} . \\
\text { tálh-lec } & \text { aylh } \quad S=\text { Mary } & \text { pro }_{E R G} . \\
\text { stand.up-AUT } & \text { then } \quad N O M=\text { Mary }
\end{array}
$$

(Davis 2006)

Below, I provide a range of empirical evidence in favor of the proposal that St'át'imcets pronouns are indefinite. I will conclude that third-person pronouns vary in their semantics cross-linguistically, and that the variation seems to be linked to independent variation in the semantics of determiners.

However, the story is not quite that simple as that. I will also show that the pronoun/determiner parallel in St'át'imcets is not complete, since unlike full DPs, pronouns can receive bound variable, E-type, and donkey interpretations. The breakdown in the pronoun/determiner parallel is illustrated for donkey anaphora in (3) vs. (4).

$$
\begin{aligned}
& \text { tákem } \begin{array}{lllll}
\mathrm{i}=\text { sqáyqeycw=a } & \text { wa7 } & \text { az' } & \text { ku=sqáxa7 } & \text { wa7 } \\
\text { all } \quad \text { DET.PL=men=EXIS IMPF } & \text { buy } & \text { DET=dog } & \text { IMPF } \\
\text { seksek-n-ítas } \quad \text { pro }_{A B S} & & & \\
\text { beat-DIR-3PL.ERG pro } \text { pros }_{A B S} & &
\end{array} \\
& \text { 'Every man who buys a dog beats it.' }
\end{aligned}
$$

$$
\begin{aligned}
& \text { \#tákem i=sqáyqeycw=a wa7 az' ku=sqáxa7 wa7 } \\
& \text { all DET.PL }=\text { men }=\text { EXIS IMPF buy DET }=\text { dog IMPF } \\
& \text { seksek-n-ítas } \quad t i=s q a ́ x 7=a \\
& \text { beat-DIR-3PL.ERG } D E T=d o g=E X I S
\end{aligned}
$$

[only means every man who buys a dog beats one particular dog, say Fido]

The challenge, then, is to find a semantics for St'át'imcets pronouns and determiners which captures the shared absence of a familiarity effect, but blocks donkey and bound interpretations for full DPs while allowing them for pronouns.

\footnotetext{
${ }^{2}$ All data come from primary fieldwork unless otherwise stated. Abbreviations used: ABS: absolutive, AUT: autonomous intransitivizer, CAUS: causative transitivizer, CIRC: circumstantial modal, COMP: complementizer, CONJ: conjunctive, DEIC: deictic, DET: determiner, DIR: directive transitivizer, EPIS: epistemic modal, ERG: ergative, FOC: focus, IMPF: imperfective, IND: indirective applicative, INSTR: instrument, NOM: nominalizer, OBJ: object, PL: plural, POSS: possessive, PREP: preposition, RED: redirective applicative, SG: singular, STAT: stative, SUBJ: subject, TEMP: temporal. Hyphens mark affix boundaries and equals signs mark clitic boundaries.
} 
The solution I will propose is as follows. St'át'imcets pronouns and determiners share a core semantics similar to that proposed by Elbourne (2005) for English it and the. The difference between the languages with respect to familiarity effects derives from an independent difference in the nature of presuppositions. As I have argued for other presupposition triggers (Matthewson 2006), the uniqueness presuppositions of pronouns and determiners do not result in a discourse familiarity effect in St'át'imcets. Finally, the absence of nonreferential interpretations for full DPs is derived from the deictic presuppositions of the overt determiners, which disallow binding of their situation argument. Full DPs are forced to pick out a unique individual in the salient discourse situation.

The analysis presented here has several theoretical consequences. It provides cross-linguistic support for the pronoun/determiner parallel proposed by Elbourne and others. It provides evidence for predictable cross-linguistic differences in the semantics of pronouns. It provides support for the idea that presuppositions in St'át'imcets do not place the same restrictions on the common ground as English presuppositions do (Matthewson 2006). Finally, it derives the wide-scope effects of full DPs in St'át'imcets via an independently-needed situation semantics, without needing to use choice functions as in Matthewson (1999, 2001). And in so doing, it offers a solution to an empirical problem for the choice function analysis pointed out by Davis (2004).

\section{St'át'imcets Third-Person Pronouns}

St'át'imcets is an endangered Northern Interior Salish language spoken in the southwest interior of British Columbia. There are three sets of third-person pronouns in the language: plain, possessive, and emphatic (the last appearing only in focused environments). I deal only with the plain set here, although possessive pronouns appear to share most if not all relevant properties with the plain set.

The default third-person pronoun in St'át'imcets is pro. pro co-occurs either with a zero absolutive agreement marker $\varnothing$, as in $(5 \mathrm{a}, \mathrm{b})$, or with an ergative agreement suffix -as, as in (5c). ${ }^{3}$
a. $\quad$ qwatsáts $=\varnothing \quad \operatorname{pro}_{A B S}$
leave $=3 A B S \quad$ pro $_{A B S}$
'He/she/they/it left.'
b. ats'x-en- $\varnothing=$ lhkan $\quad$ pro $_{A B S}$
see-DIR- $3 A B S=1$ SG.SUBJ pro $_{A B S}$
'I saw him/her/them/it.'
c. ats'x-en-túmulh-as pro ${ }_{E R G}$
See-DIR-1PL.OBJ-3ERG $\quad \operatorname{pro}_{E R G}$
'He/she/they/it saw us.'

\footnotetext{
${ }^{3}$ On the affixal vs. clitic status of the endings, see Davis (2000b).
} 
In the absolutive plural, with a human referent, there is an optional overt pronoun wit. ${ }^{4}$ Davis (2003) argues on the basis of extraction and other evidence that unlike the ergative suffix - as or the zero absolutive $\varnothing$, wit is a real pronoun, not an agreement (see also Roberts 1999). Thus, in (6), there are no pros. The wit is itself the pronoun.

$$
\begin{aligned}
& \text { a. } \text { qwatsáts }=\text { wit } \\
& \text { leave }=3 P L \\
& \text { 'They left.' }
\end{aligned}
$$

b. ats'x-en-wit $=$ kan see-DIR- $3 P L=1 \mathrm{SG} . \mathrm{SUBJ}$

'I saw them.'

For the rest of the paper, I will only show pros in example sentences if they are relevant, and I will not mark zero absolutive agreement.

The first empirical generalization to be established is that pro and wit share all the interpretations of English third-person pronouns: they have referential, bound variable, donkey, and other E-type interpretations. Referential pronouns are illustrated in (7-8). In each case, the pronoun in the last sentence refers to the individual(s) introduced in the preceding sentence(s).

$$
\begin{aligned}
& \text { wá7=lhkan lexláx-s } \quad t a=n \text {-spápz7 }=a \\
& \text { IMPF }=1 \mathrm{SG} . \text { SUBJ remember-CAUS DET=1SG.POSS-grandfather }=\text { EXIS } \\
& s=\text { Síkil, pináni7 } \quad \mathrm{i}=\mathrm{w}=\text { at } \\
& N O M=\text { Sikil TEMP.DEIC when.PAST=IMPF }=1 \text { PL.CONJ } \\
& \begin{array}{llll}
\text { ka-gúy't-a } & \mathrm{lh}=\mathrm{at} & \text { wa7 } & \text { ílhen } \\
\text { CIRC-sleep-CIRC } & \text { COMP(IMPF)=1PL.CONJ } & \text { IMPF } & \text { eat }
\end{array}
\end{aligned}
$$

'I remember my grandfather Síkil, when we had fallen asleep while eating.'

$$
\begin{aligned}
& \text { nilh=tu7 } \mathrm{s}=\mathrm{e}=\mathrm{s} \quad \text { kwan-túmulh-as } \operatorname{pro}_{E R G} \text { nilh } \\
& \mathrm{FOC}=\mathrm{PAST} \mathrm{NOM}=\mathrm{IMPF}=3 \text { POSS take(DIR)-1PL.OBJ-3ERG } \text { pro }_{E R G} \quad \text { FOC } \\
& \mathrm{s}=\mathrm{a}=\mathrm{s} \quad \text { tsicw-s-tumúlh-as áta7 ta }=\text { sk'ém'ts }=\mathrm{a} \\
& \mathrm{NOM}=\mathrm{IMPF}=3 \text { POSS get.there-CAU-1PL.OBJ-3ERG DEIC DET }=\text { door }=\text { EXIS }
\end{aligned}
$$

'He would get us and take us to the door.' (Matthewson 2005:186)

(8) nilh ni=wa7 tsún-itas James Link skwátsits-s=a

FOC DET=IMPF say(DIR)-3PL.ERG James Link name-3POSS=EXIS

'James Link was his name.'

múta7 i=sésq'wez'-s=a George Link múta7 Felix Link

and DET.PL=younger.sibling=EXIS George Link and Felix Link

'And his younger brothers were George Link and Felix Link.'

\footnotetext{
${ }^{4}$ wit does not appear in object position when there is a third person subject.
} 
plan=wit $=$ tu $7 \quad$ aylh tákem wa7 zuqw already $=3 P L=$ PAST then all IMPF die

'They've all already died.' $\quad$ (Matthewson 2005:124)

Bound pronoun uses of pro and wit are shown in (9-10).

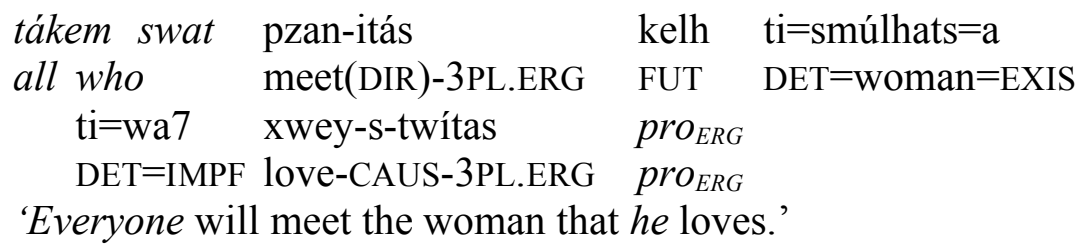

(10) tákem swat wa7 tsut-ánwas $\mathrm{k}=\mathrm{wa}=\mathrm{s} \quad$ lexlex=wit all who IMPF say-inside $\mathrm{DET}=\mathrm{IMPF}=3 \mathrm{POSS} \quad$ smart $=3 P L$ 'Everyone thinks they are smart.' [= each person thinks they themselves are smart]

Donkey pronouns are illustrated in (11-12); examples are given only with pro, as wit does not appear in a clause with two third-person arguments, as mentioned in footnote 4 . The comment given by the consultant for (12) supports the claim that these sentences have typical (universal) donkey-interpretations.

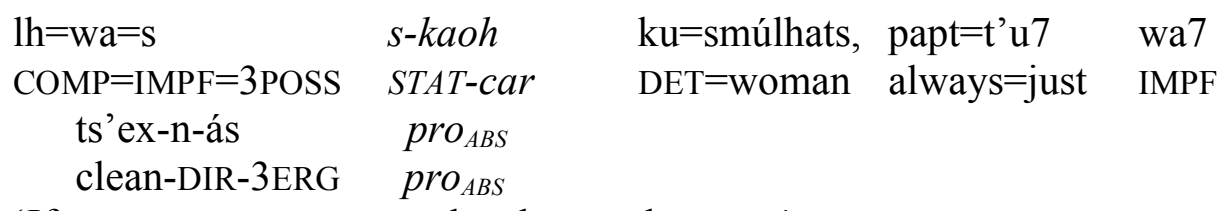

'If a woman owns a car, she always cleans it.'

tákem i=sqáycw=a wa7 s-qáxa7 wa7 sek-en-ítas pro $_{A B S}$ all DET.PL=man=EXIS IMPF $S T A T-d o g$ IMPF hit-DIR-3PL.ERG pro $_{A B S}$ 'Every man that has a dog hits it.'

If one man has five dogs and only hits one of them: "Sounds wrong."

Finally, pro and wit may also function as (other types of) E-type pronouns. As this generalization has not been established before, I give a range of E-type pronoun cases in (13-17).

$$
\begin{aligned}
& \text { wa7 tsutánwas } \mathrm{k}=\mathrm{John} \quad \mathrm{kw}=\mathrm{s}=\mathrm{cuz} \quad \quad \text { kwámem } k u=t s^{\prime} \text { 'úwaz' } \\
& \text { IMPF think DET }=\text { John } \mathrm{DET}=\text { nom }=\text { going.to take } D E T=\text { fish } \\
& \text { nílh=t'u7 xát'-min'-as } \quad \mathrm{kw}=\mathrm{en}=\mathrm{cuz} \quad \text { q'wél-en } \text { pro }_{A B S} \\
& \text { FOC=just want-RED-3ERG DET=1SG.POSS=going.to cook-DIR pro } \text { prS }_{A B S}
\end{aligned}
$$

$\begin{array}{llll}\text { kan } & \text { xát'-min' } & \mathrm{kw}=\mathrm{n}=\mathrm{s}-\text { tsmal't, } & \text { nilh } \\ \text { 1SG.SUBJ } & \text { want-RED } & \text { DET-1SG.POSS-STAT-offspring } & \text { FOC }\end{array}$




$$
\begin{array}{lll}
\mathrm{ku}=\mathrm{n}=\mathrm{k} \text { 'ul' }-\mathrm{s}-\text { wit } & \mathrm{ku}=\mathrm{wa} 7 & \text { baseball } \\
\mathrm{DET}=1 \mathrm{SG} . \mathrm{POSS}=\text { make-CAUS-3PL } & \text { DET-IMPF } & \text { baseball }
\end{array}
$$

'I want to have some children and teach them to play baseball.'

$$
\begin{aligned}
& \text { tqilh=t'u7 tákem i=s-cín'=a kaoh wa7 s-radio; } \\
& \text { almost }=\text { just all DET.PL-NOM-long.time=EXIS car IMPF STAT-radio } \\
& \mathrm{l}=\mathrm{ki}=\mathrm{núkw}=\mathrm{a}, \quad \text { kéla7=t'u7 wa7 áma } \text { pro }_{A B S} \\
& \mathrm{PREP}=\mathrm{DET} . \mathrm{PL}=\mathrm{other}=\mathrm{EXIS} \text { first }=\text { just } \quad \mathrm{IMPF} \text { good } \text { pro }_{A B S}
\end{aligned}
$$

'Almost all old cars have a radio. In some of them, it is a really good one.'

$$
\begin{aligned}
& \text { tákem i=wa7 tsilkst szánucwem sk'wemk'úk’wmi7t wa7 } \\
& \text { all DET.PL-IMPF five year children IMPF } \\
& \text { ama-s-twítas (i)=skicez7-i=ha, k'ámalh } \\
& \text { good-CAUS-3PL.ERG (DET.PL)=mother-3PL.POSS }=\text { EXIS but } \\
& \mathrm{i}=\text { lán=a q'em'p wi=tsilkst syéy'qtsa7 } \\
& \text { DET.PL }=\text { already }=\text { EXIS ten } \quad 3 \mathrm{PL}=\text { five } \text { girl } \\
& \text { qvl-s-twítas } \text { pro }_{A B S} \\
& \text { bad-CAUS=3PL.ERG } \text { pro }_{A B S}
\end{aligned}
$$

'Every five-year-old girl loves her mother, and every 15-year old girl hates her.'

(17) Context ("paycheck sentence"): Two women won at bingo last night.

$$
\begin{aligned}
& \text { p'a7cw s=léxlex }=\mathrm{s} \quad \text { ta }=\text { uxwal'-s-táli=ha } \\
& \text { more } \quad \mathrm{NOM}=\text { smart }=3 \text { POSS } \quad \mathrm{DET}=\text { go.home-CAUS-TOP }=\text { EXIS } \\
& \text { ta }=\text { sqláw' }-s=a \quad \text { lhél }=\text { ta }=\text { pel'p-s-táli=ha } \text { pro }_{A B S} \\
& D E T=\text { money }-3 P O S S=E X I S \text { PREP }=\mathrm{DET}=\text { lost-CAUS-TOP=EXIS } \text { pro }_{A B S} \\
& \mathrm{l}=\mathrm{ta}=\text { bus }=\mathrm{a} \\
& \mathrm{PREP}=\mathrm{DET}=\text { bus }=\text { EXIS }
\end{aligned}
$$

'The one who took her money home was smarter than the one who left it on the bus.'

Summarizing so far, we have seen that the two plain third-person pronouns in St'át'imcets, pro and wit, share all the core interpretations of English pronouns. No variation is apparent yet.

\section{A Difference Between St'át'imcets and English Third-Person Pronouns}

In this section I will argue that in spite of the similarities seen so far between English and St'át'imcets third-person pronouns, there is one striking difference between pronouns in the two languages. As already proposed by Davis (2006), the St'át' imcets pronouns induce no familiarity effects. ${ }^{5}$

The first type of data involves oral narratives with initial sentences containing pronouns whose reference is not determined until later. An example is

\footnotetext{
${ }^{5}$ Davis et al. (2007) also make the same point for Nuuchahnulth (Wakashan).
} 
given in (18), which is the first line of the story 'The Swimmer' by Sam Mitchell. The translators of the story have made the English version felicitous by inserting a full noun phrase, where the St'át'imcets version simply uses pro.

$$
\begin{array}{cllll}
\text { wa7 } \text { pro }_{A B S} \text { áku7 } & \text { káti7, ka-7ats'x-s-ás-a } & \text { 1t7u } \\
\text { be } \text { pro }_{A B S} \text { DEIC } & \text { DEIC } & \text { CIRC-see-CAUS-3ERG-CIRC } & \text { DEIC } \\
\text { x71'lh=a } & \text { i=wa7 } & \text { záw-em } & \\
\text { other.side-DET } & \text { DET.PL=IMPF } & \text { fish-MID } &
\end{array}
$$

Literal translation: 'He was there, he caught sight of the ones who were fishing over on the other side.'

Felicitous English translation: 'There was this man ...'

(van Eijk and Williams 1981:72)

Another example, which involves possessive pronouns but makes the same point, is given in (19). This is the first line of the story 'Grizzly Bear and Black Bear's Children' by Adelina Williams. The sentence introduces the topical discourse referents, the bear cubs, only by referring to them via pronouns. Note that the cubs themselves are not digging; thus, the some bears in the English gloss does not introduce a discourse referent for the cubs.

$$
\begin{aligned}
& \text { wa7 kém'-em } \mathrm{i}=\text { míxalh }=\mathrm{a}, \quad \mathrm{ti}=\text { sqatsez7 }-i=\text { ha } \\
& \text { IMPF dig.roots-MID DET.PL=bear=EXIS DET-father-3PL.POSS =EXIS } \\
& \text { múta7 ti-skicez7- } i=\text { ha } \\
& \text { and DET=mother-3PL.POSS=EXIS (van Eijk and Williams 1981:14) }
\end{aligned}
$$

Of course, even in English, stories sometimes begin with out-of-the-blue definite descriptions or pronouns, and the reader is expected to accommodate the familiarity presupposition. It is also possible that even though (18) and (19) are apparently discourse-initial, there was some prior agreement about which story was going to be told, and therefore that the referents were familiar to the hearers. More convincing evidence for non-familiar pronouns therefore actually comes from cases in the middle of stories, since here the discourse context is clear. Examples of this type are given in (20-21). In (20), the third line contains a wit which comes out of the blue; at this stage of the discourse we have no idea who left to go back down the hill. The reference is resolved in the following sentence by the mention of boys, but the literal English translation still sounds very odd.

$$
\begin{aligned}
& \text { t'íq=kalh ti=cácl'ep=a } \\
& \text { arrive }=1 \text { PL.SUBJ } \quad \text { DET }=\text { Fountain }=\text { EXIS } \\
& \text { 'We arrived up at Fountain.' } \\
& \text { q'íl=lhkalh áku7, wá...7=lhkalh káku7, } \\
& \text { get.on.top=1PL.SUBJ DEIC be=1PL.SUBJ DEIC } \\
& \text { 'We got there, we stayed there for a while,' }
\end{aligned}
$$


$\begin{array}{lll}\text { qwatsáts }=\text { wit } & \text { súxwast } & \text { múta7 } \\ \text { leave }=3 P L & \text { descend } & \text { again } \\ \text { 'and then } & \text { they left to go back down the hill.' }\end{array}$

slhay káti7 ku=s=záyten-s ku=twéw'w'et overconfident DEIC DET=NOM=business=3POSS DET=boys 'You know how boys think they can do anything.'

('The Truck Rolls' by Bill Edwards)

(21) is a similar case. Here, the pronoun reference is never explicitly resolved.

$\begin{array}{lll}\text { pákw=kalh-a } & \text { tsicw } & \text { kent7ú pankúph=a } \\ \text { set.off=1PL.SUBJ-CIRC } & \text { get.there } & \text { DEIC Vancouver=EXIS } \\ \text { 'We left and went back to Vancouver.' } & \end{array}$

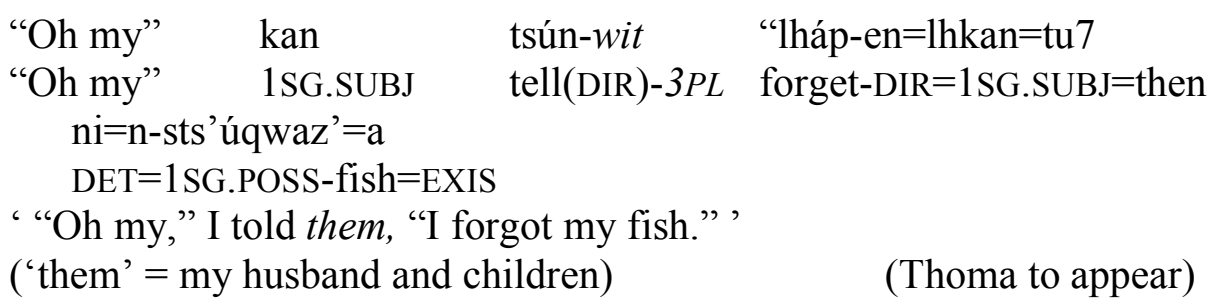

The non-familiarity of pro and wit is also evidenced in fieldwork situations. Although caution is required due to the unnaturalness of the elicitation environment, it is striking that backwards pronominalizations are easy to obtain, and crucially are acceptable in constructions in which the corresponding English glosses are infelicitous. Examples are given in (22-23); see also (2) above. ${ }^{6}$

$$
\begin{aligned}
& \left.\mathrm{ni}=\mathrm{s}-\text { pála7-s=a [q'7-ál'men } \text { pro }_{A B S}\right] \text {, nilh }[\mathrm{s}=\text { wa7 }=\mathrm{s} \\
& \left.\mathrm{DET}=\mathrm{NOM}-\mathrm{one} 3 \mathrm{POSS}=\mathrm{EXIS} \text { eat-want } \text { pro }_{A B S}\right] \text { then }[\mathrm{NOM}=\mathrm{IMPF}=3 \mathrm{POSS} \\
& \text { cwíl'-em } \quad t i=n k \text { yáp }=a \quad \mathrm{ku}=\mathrm{sq} \text { 'a7-s] } \\
& \text { seek-MID } \quad D E T=\text { coyote }=E X I S \quad \text { DET }=\text { food-3POSS }]
\end{aligned}
$$

$$
\begin{aligned}
& \text { na }=\text { s-pála7 }-\mathrm{s}=\mathrm{a} \quad[\text { táyt }=\text { wit }], \quad \text { nilh } \quad[\mathrm{s}=\text { wa7 }=\mathrm{s} \\
& \mathrm{DET}=\mathrm{NOM} \text {-one-3POSS }=\text { EXIS }[\text { hungry }=3 P L] \text { then }[\mathrm{NOM}=\mathrm{IMPF}=3 \mathrm{POSS} \\
& \text { cwíl'-em } \mathrm{ku}=\mathrm{s} 7 \text { ílhen } t a=n k \text { yáp }=a \quad \text { múta } \mathrm{ta}=\text { sxgwálcw }=a \text { ] } \\
& \text { seek-MID DET=food DET }=\text { coyote }=E X I S \text { and } D E T=\text { fox }=E X I S]
\end{aligned}
$$

'Once upon a time, they $y_{i}$ were hungry, so $[\text { a coyote and a fox }]_{i}$ went looking for food.'

(Davis 2006)

The data presented in this section show that pro and wit are routinely volunteered and accepted in contexts in which their reference is not (yet) clear

\footnotetext{
${ }^{6}$ The element nilh in these examples is a clausal conjunction, and may not conjoin VPs; see Davis (2000a). This rules out an alternative syntactic structure for e.g., (22) whereby two VPs are coordinated and there is no pro in the first conjunct.
} 
from the discourse context. I conclude that these St'át'imcets pronouns have no familiarity requirement.

\subsection{Further Evidence for Indefinite Pronouns}

If pro and wit are not definite, then they should be felicitous in prototypical indefinite environments such as existential sentences and sluicing contexts. ${ }^{7}$ As far as the language allows us to test this prediction, it is upheld.

(24) illustrates the St'át'imcets existential construction. The sentence is introduced by the locative-existential predicate wa7; a pivot follows, which may not be a strongly quantified phrase.

$$
\begin{aligned}
& \text { wa7 }[* \text { tákem } / \text { cw7it } \mathrm{i}=\text { ucwalmícw=a }] \quad \text { láku7 } \mathrm{l}=\mathrm{ti}=\mathrm{lep} \text { 'cálten=a } \\
& \text { be }[\text { all } / \text { many } \quad \text { DET.PL=person=EXIS }] \text { DEIC in-DET-garden=EXIS } \\
& \text { 'There are *all / many people in the garden.' }
\end{aligned}
$$

Placing a pronoun into the pivot position results in an acceptable sentence:

(25) Context: You are sitting eating breakfast looking out at your garden and you see two people walking in the garden. You tell your grandson:

$$
\begin{aligned}
& \text { wá7=wit láku7 } \quad \mathrm{l}=\mathrm{ti}=\text { lep'cálten=a } \\
& \text { be=3PL } \quad \text { DEIC } \quad \text { PREP=DET=garden=EXIS } \\
& \text { 'There's them } \text { in the garden.' }
\end{aligned}
$$

There is an unavoidable wrinkle with (25), since the sentence has an alternative structural analysis as 'They are in the garden'. Under this analysis, the wit is simply the subject of the locative predicate wa7 and we may not be dealing with an existential construction per se. However, it is significant that wit is grammatical in a construction in which strong quantifiers are ruled out (cf. (24)). Furthermore, even the alternative structure illustrates an absence of familiarity effects. The acceptability of (25) clearly contrasts with the English 'They are in the garden', which is infelicitous in the given discourse context.

A similar situation obtains with sluicing (Chung et al. 1994). The data in (26-27) show that sluicing-like structures are felicitous in St'át'imcets with the pronouns pro or wit in the position of the necessarily indefinite noun phrase.

(26) Context: You are going camping in a camping ground and you start setting up your tent. A guy comes around and says that he is the attendant and tells you to pay him \$20 for the night. You pay him, even though you're not really sure if he is the right guy or not. Then your husband comes back and you tell him:

$$
\begin{array}{lllll}
\text { xáq'-en=lhkan } & \text { pro }_{A B S}, & \text { t'u7 } & \text { áoy=t'u7 } & \mathrm{kw}=\mathrm{en}=\text { zwát-en } \\
\text { pay-DIR=1SG.SUBJ } & \text { pro }_{A B S} & \text { but } & \mathrm{NEG=just} & \mathrm{DET}=1 \mathrm{SG} . P O S S=k n o w-D I R
\end{array}
$$

\footnotetext{
${ }^{7}$ Thanks to Hotze Rullmann (p.c.) for suggesting these tests.
} 
lh $=$ swát $=$ as

$\mathrm{COMP}=$ who $=3 \mathrm{CONJ}$

'I paid him, but I don't know who.'

(27) Context: You like to go for late-night walks on the reserve when it's all peaceful. No-one else does that, so you never see anyone. But tonight you saw two people in the distance. When you get home you tell your husband (discourse-initially):

$$
\begin{aligned}
& \mathrm{i}=\mathrm{w}=\mathrm{an} \quad \text { mám'teq ats'x-en-wit }=\mathrm{kan}, \quad \mathrm{t} \text { 'u7 } \\
& \text { when.PAST }=\mathrm{IMPF}=1 \mathrm{SG} . \mathrm{CONJ} \text { walk see-DIR-3PL=1SG.SUBJ but } \\
& \text { áoy }=\mathrm{t} \text { 'u } \quad \mathrm{kw}=\mathrm{en}=\mathrm{zwát}=\mathrm{en} \quad \mathrm{lh}=\mathrm{swát}=\mathrm{as} \\
& \mathrm{NEG}=\text { just } \quad \mathrm{DET}=1 \mathrm{SG} . \mathrm{POSS}=\mathrm{know}-\mathrm{DIR} \quad \mathrm{COMP}=\text { who }=3 \mathrm{CONJ}
\end{aligned}
$$

As with the existential sentences, there are language-specific reasons why (26-27) may not actually be cases of sluicing. In St'át'imcets, wh-words function as predicates, so it is impossible to prevent the structure from involving a full 'who it was' clause (Henry Davis, p.c.). However, (26-27) still illustrate the nonfamiliarity of the pronouns. The English counterparts containing definite him or them are quite infelicitous in the given discourse contexts.

In summary, we have used a variety of discourse contexts and three (in)definiteness tests, and in no case was there any evidence for a definiteness or familiarity effect with St'át'imcets pro and wit. I conclude that these pronouns do not carry familiarity presuppositions, and thus that they differ in their semantics from English third-person pronouns.

\section{A Parallel Between St'át'imcets Pronouns and Determiners}

In this section I will show that the lack of familiarity effects demonstrated above for pro and wit is shared by St'át'imcets determiners.

St'át'imcets possesses two kinds of determiners, neither of which is definite. One set are polarity items which are infelicitous in most definite environments; see Matthewson (1998) for discussion. The second set of determiners, which all include an enclitic $=a$, are shown in (28). They encode distinctions of plurality and spatial distance from the speaker of the utterance.

(28) St'át'imcets determiners (adapted from Matthewson 1998, van Eijk 1997):

\begin{tabular}{|l|c|c|c|c|}
\cline { 2 - 4 } \multicolumn{1}{c|}{} & present & absent & invisible \\
\hline - plural & $t i=\ldots=a^{8}$ & $n i=\ldots=a$ & $k u=\ldots=a$ \\
\hline \multirow{2}{*}{+ plural } & -collective & $i=\ldots=a$ & $n e l h=\ldots=a$ & $k w e l h=\ldots=a$ \\
\cline { 2 - 5 } & + collective & \multicolumn{3}{|c}{$k i=\ldots=a$} \\
\hline
\end{tabular}

\footnotetext{
${ }^{8}$ Dialectal variant $t a=\ldots=a$
} 
In Matthewson $(1998,1999)$ I showed that the determiners ending in $=a$ are (i) felicitous in both novel and familiar contexts; (ii) felicitous in existential sentences; and (iii) good in sluicing-like contexts. For reasons of space I will illustrate only the first property here. In (29), all three sentences come from the same story. The novel introduction of the shoemaker in the first line and the policeman in the second line contain the determiner $t i=\ldots=a$; the same determiner is used to refer to the familiar policeman in the third line.
wa7 ti7 láti7 $[t i=$ sumíkh $=a]$
lts $7 \mathrm{a}$ táown $=\mathrm{a}$
IMPF DEMON DEIC $\quad[D E T=$ shoemaker $=E X I S]$
DEIC town=EXIS

'Once there lived this shoemaker here in town.'

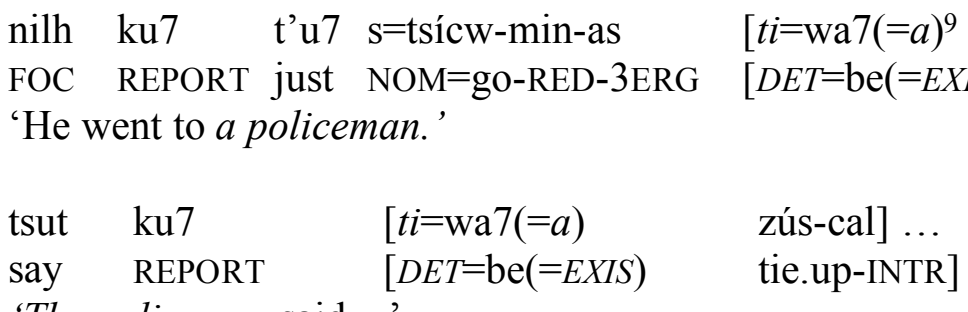

'The policeman said ...'

(van Eijk and Williams 1981:76; cited in Matthewson 1998)

We have now seen that St'át'imcets determiners and pronouns both lack familiarity effects, and it would obviously be a good idea to derive these two facts from one generalization. The St'át'imcets facts suggest that it might be possible to generalize Elbourne's $(2001,2005)$ proposal that in English, pronouns are definite determiners. Perhaps in general, the semantics of third-person pronouns in a language $L$ is based on the semantics of determiners in $L$, whatever that is. In the next section I begin to explore this idea.

\section{Pronouns as Determiners}

As mentioned above, Elbourne's plan to collapse third-person pronouns with definite determiners relies largely on the semantic equivalence between (30a-b).

(30) a. Every man who owns a donkey beats $i t$.

b. Every man who owns a donkey beats the donkey.

With the pronoun, NP-deletion takes place, as shown in (31). The LFs for the two sentences are therefore essentially identical, given the equivalence between it and the (Elbourne 2005:42).

(31) Every man who owns a donkey beats it donkey.

Unlike many of the authors cited above who have analyzed pronouns as

\footnotetext{
${ }^{9}$ The enclitic portion of the determiner phonologically deletes after wa7.
} 
disguised definite descriptions, Elbourne explicitly equates the pronoun with the definite determiner itself. He also generalizes the pronoun-determiner correlation to all interpretations of pronouns, including referential and bound variable uses. For Elbourne, then, all third-person pronouns are definite articles, with a phonologically null NP argument. With donkey pronouns, the deleted NP argument is an ordinary NP. With referential and bound variable pronouns, the $\mathrm{NP}$ argument is an index. ${ }^{10}$

Elbourne's denotation for the is given in (32). It utilizes a situation semantics approach, following Berman (1987), Heim (1990), von Fintel (1994).

$$
\llbracket \text { the } \rrbracket^{\mathrm{g}}=\llbracket i t \rrbracket^{\mathrm{g}}=\lambda \mathrm{f}_{<<\mathrm{s}, \mathrm{e}>,<\mathrm{s}, \mathrm{t}>>} \cdot \lambda \mathrm{s}: \exists ! \mathrm{xf}(\lambda \mathrm{s} . \mathrm{x})(\mathrm{s})=1 . \operatorname{tx} \mathrm{f}\left(\left(\lambda \mathrm{s}^{\prime} \cdot \mathrm{x}\right)(\mathrm{s})=1\right.
$$

(Elbourne 2005:51)

According to (32), the takes as arguments an NP and a situation, which is presupposed to contain exactly one element satisfying that NP predicate. The entire definite DP then denotes the unique individual which satisfies the NP in that situation. (31a-b) therefore (roughly) assert that: every minimal situation $\mathrm{s}_{1}$ containing a man and a donkey he owns is part of an extended situation $s_{2}$ in which the unique man in $s_{2}$ beats the unique donkey in $s_{2}$. Because there is only one donkey and one man in $s_{2}$, we correctly predict that each man beats the donkey he owns in $\mathrm{s}_{1}$. Since this is true for every minimal situation $\mathrm{s}_{1}$ containing a man-owning-donkey pair, we correctly predict that every man beats all the donkeys he owns.

\section{Analysis}

We want to analyze pronouns as (basically) determiners, to capture the parallelism in their non-familiar semantics. We also need a denotation for the pronouns which allows donkey-binding, as well as all the other interpretations of pronouns. Let's start with Elbourne's (2005:51) denotation for it, which satisfies the latter requirements:

$$
\llbracket i t \rrbracket^{\mathrm{g}}=\lambda \mathrm{f}_{<<\mathrm{s}, \mathrm{e}>,<\mathrm{s}, \mathrm{t}>>} \cdot \lambda \mathrm{s}: \exists ! \mathrm{xf}(\lambda \mathrm{s} . \mathrm{x})(\mathrm{s})=1 . \mathrm{xx} \mathrm{f}\left(\left(\lambda \mathrm{s}^{\prime} . \mathrm{x}\right)(\mathrm{s})=1\right.
$$

For St'át'imcets, there is an apparent problem with (32), namely the uniqueness presupposition. For English, the uniqueness presupposition of (32) is expected, because English third-person pronouns are definite. But we have seen that in St'át'imcets the pronouns, just like the full DPs, are not definite.

There are a couple of possible routes we could take to solve this problem. One possibility would be to alter Elbourne's denotation by deleting the offending presupposition. However, Elbourne (following Heim and others) needs the uniqueness presupposition on the pronoun to ensure that the right men beat the

\footnotetext{
${ }^{10}$ Tomioka (2003) also finds striking parallels between the interpretations of Japanese pro and those of full Japanese DPs. Interestingly, Japanese pro allows interpretations St'át'imcets pro does not, involving existential closure.
} 
right donkeys. Recall that Elbourne's denotation derives that fact that in (31), every minimal situation $s_{1}$ containing a man and a donkey he owns is part of an extended situation $\mathrm{s}_{2}$ in which the unique man in $\mathrm{s}_{2}$ beats the unique donkey in $\mathrm{s}_{2}$. Because there is only one donkey and one man in $s_{2}$, we correctly predict that each man beats the donkey he owns in $s_{1}$ (see Elbourne 2005:52). Without the uniqueness presupposition, we simply do not derive the correct semantics for a donkey sentence; thus, this option appears to be a non-starter. Note also that the presupposition on the donkey pronoun is used by von Fintel (1994:158ff) to derive the anomaly of (33) and other similar cases:

$$
\text { \#If there isn't a donkey in the backyard, we should feed it. }
$$

The St'át'imcets counterparts of cases like (33) are infelicitous just as in English, as shown in (34). This again suggests that we cannot simply do away with the presupposition.

$$
\begin{aligned}
& \text { \#lh=cw7áoz=as káku7 ku=ts'í7 } \quad \mathrm{l}=\mathrm{ti}=\text { lep'calten-lhkálh=a, } \\
& \mathrm{HYP}=\mathrm{NEG}=3 \mathrm{CONJ} \text { DEIC } \mathrm{DET}=\mathrm{deer} \quad \mathrm{PREP}=\mathrm{DET}=\text { garden-1PL.POSS=EXIS } \\
& \text { áma=ka } \mathrm{lh}=\mathrm{am} \text { 'ts-án'-m=as } \\
& \text { good=IRR } \mathrm{COMP}=\text { feed-DIR-1PL.ERG=CONJ } \quad \text { pro }_{A B S} \\
& \text { 'If there isn't a deer in the garden, we should feed it.' }
\end{aligned}
$$

A second option to deal with the problematic presupposition would be to claim that (32), in spite of involving a uniqueness presupposition, does not involve familiarity. This would mean that we could adopt (32) for St'át'imcets pronouns, but for English pronouns, we would need to add some extra familiarity requirement.

The debate about familiarity vs. uniqueness in English definite descriptions has a long history; see Heim (1982, 1983), Kadmon (1987), Hawkins (1991), Birner and Ward (1994), Abbott (1999, 2003, 2005), Ludlow and Segal (2002), Szabo (2000, 2003), among many others, for discussion. It is not my goal to add to this debate, and I will remain agnostic on how the familiarity effect for English definites is derived. However, the analysis I will argue for below does rely on the idea that what differentiates English and St'át'imcets pronouns and determiners is not uniqueness, but familiarity. The core generalization is as follows: while in both languages, pronouns have uniqueness effects, only in English do pronouns have a familiarity effect. ${ }^{11}$ I will achieve this result not by altering Elbourne's denotation for English definites, but rather by relying on a language-wide parametric difference in the nature of presuppositions, which I have previously proposed on the basis of other presupposition triggers (Matthewson 2006). Once we accept that in the entire St'át'imcets language, presuppositions have a different discourse effect than they do in English, we will be able to adopt Elbourne's (32) for both languages and derive the correct results.

The basic claim (see Matthewson 2006) is that presuppositions in

\footnotetext{
${ }^{11}$ In Matthewson (in press) I propose something similar for St'át'imcets nukw 'some, other', which possesses a non-maximality presupposition but lacks the familiarity effect of English other.
} 
St'át'imcets do not place the same constraints on the common ground as English presuppositions do. The core fact which led me to make this proposal is that von Fintel's (2004) 'Hey, wait a minute!' test fails to apply in St'át'imcets. The HWAM test is illustrated in (35), from von Fintel (2004:271). We see that it is felicitous to challenge a failed presupposition with an expression of surprise, but it is not felicitous to challenge an previously unknown assertion in the same way. The test thus provides an excellent way to detect presuppositions as opposed to asserted material.

(35) A: The mathematician who proved Goldbach's Conjecture is a woman.

B: Hey, wait a minute. I had no idea that someone proved Goldbach's Conjecture.

B': \#Hey, wait a minute. I had no idea that that was a woman.

In St'át'imcets, elements which correspond to a range of English presupposition triggers have been tested (e.g., words for 'again', 'also', 'stop', 'more', and cleft constructions). Failure of the hypothesized presuppositions are never challenged by hearers in a way which distinguishes failed presuppositions from new asserted information. One example is given in (36).

(36) Context: A couple are in love and decide to get married. As far as she knows, he has never been married before. He says to her:

áma n-scwákwekwekw=a $\mathrm{kw}=\mathrm{en}=\mathrm{s}=\mathrm{cuz}$ melyíh múta 7 good 1SG.POSS-heart=EXIS DET=1SG.POSS=NOM=going.to marry again 'I'm happy to be getting married again.'

What would she reply?

áma t'it n-scwákwekw=a

good also 1sG.POSS-heart=EXIS

'I'm also happy.'

The use of múta7 'again' in (36) does not phase the consultant in the slightest, and she does not offer a HWAM response. The reader is referred to Matthewson (2006) for similar results for a range of other presupposition triggers.

Data such as this have led me to argue that the St'át'imc language as a whole does not require presuppositions to be shared knowledge between speaker and hearer. Thus, I analyze the elements which correspond to English presupposition triggers as also triggering presuppositions in St'át'imcets, but of a different type. Following Gauker's (1998) analysis of English (which, however, I reject for English, following von Fintel 2000), I argue that a presupposition in St'át'imcets merely represents the speaker's own take on the propositional context (where the propositional context contains propositions that 'are relevant to the conversational aims of the interlocutors, whether they are aware of these facts or not' (Gauker 1998:150)). The effect of this is that it looks in St'át'imcets like 
accommodation always takes place (except if the accommodated presupposition is necessarily false). This means that although presuppositions exist in St'át'imcets, we won't detect them as easily as in English. Once we adopt this analysis, we can use Elbourne's (32) for St'át'imcets pronouns, and still predict the absence of familiarity effects. ${ }^{12}$

The claim that the St'át'imcets elements do possess presuppositions, which nevertheless do not give rise to HWAM effects, is supported by the fact that consultants will give meta-linguistic judgments that utterances involving presupposition failure 'should not be said'. These judgments survive even under negation and other presupposition holes. With respect specifically to the pronouns, the account predicts that the uniqueness presupposition of St'át'imcets pro will be detectable in cases apart from donkey sentences, even though it does not place a restriction on the common ground. This is shown in (37), where the singular determiner is rejected in a case where the referent is non-unique.

Context: There are two cups, which both look exactly the same, on the table. I want one to pour my coffee into it. I ask you: ${ }^{13}$

\begin{tabular}{|c|c|c|}
\hline $\begin{array}{l}\text { \#sima7-cí-ts } \\
\text { come.here-IND-1SG.OBJ } \\
\text { 'Give me the cup.' }\end{array}$ & $\begin{array}{l}\text { ti }=\text { zew'áks } \\
\text { DET }=\text { cup }=\end{array}$ & \\
\hline sima7-cí-ts & ku=pála7 & zew’áksten \\
\hline $\begin{array}{l}\text { come.here-IND-1SG.OBJ } \\
\text { 'Give me one cup.' }\end{array}$ & $\mathrm{DET}=$ one & cup \\
\hline
\end{tabular}

If the determiner ti...a had no uniqueness presupposition, there would be no reason for the first reply in (37) to be bad.

In summary, we can adopt Elbourne's (32) directly for St'át'imcets pro (with a plural version for wit), correctly accounting for both the donkey interpretations as well as for the fact that St'át'imcets pronouns, while possessing uniqueness presuppositions, can be used in novel contexts. The cross-linguistic variation in familiarity effects for pronouns/Ds derives from a broader lack of familiarity effects in the entire St'át'imc language.

\section{A Non-Parallel Between Pronouns and Full DPs}

Now we turn to a complication. It turns out that in spite of the parallels discussed so far between St'át'imcets pronouns and full DPs, the two classes actually differ on almost all the core interpretations: unlike pronouns, full DPs allow only

\footnotetext{
${ }^{12}$ There is of course a large current literature on the nature of presuppositions and whether and how they affect the felicity of discourse, which I cannot address here; see Beaver (2001), Zeevat (2003), Abusch (2005), Simons (2001, 2006a,b), Schlenker (2008a,b), among many others.

${ }^{13}$ See Gillon (2006) for a different result in Skw $\underline{x} w \mathbf{7 m e s h}$ Salish, where the counterpart determiner to St'át' imcets $t i \ldots a$ can be used in the situation in (37).
} 
referential interpretations. This is schematized in (38). ${ }^{14}$

\begin{tabular}{|l|c|c|}
\cline { 2 - 3 } \multicolumn{1}{l|}{ interpretation } & pronouns & full DPs \\
\hline referential & $\sqrt{ }$ & $\sqrt{ }$ \\
\hline bound variable & $\sqrt{ }$ & $\mathrm{x}$ \\
\hline donkey & $\sqrt{ }$ & $\mathrm{x}$ \\
\hline other E-type & $\sqrt{ }$ & $\mathrm{x}$ \\
\hline
\end{tabular}

(39-40) show that St'át'imcets does not allow bound variable readings of full DPs.

$$
\begin{aligned}
& \text { qwal'út.-s-as } \quad \mathrm{s}=\text { Mary tákem } \mathrm{i}=\text { kúkwpi7=a } \quad \text { kéla7 } \\
& \text { talk-CAUS-3ERG } \quad \mathrm{NOM}=\text { Mary all } \quad \text { DET.PL }=\text { chief }=\text { EXIS first } \\
& \mathrm{s}=\mathrm{tsicw}=\mathrm{s} \quad t i=k u ́ k w p i 7=a \quad \mathrm{l}=\mathrm{ti}=\mathrm{q} \text { 'élza7ten }=\mathrm{a} \\
& \text { NOM=went }=3 \text { POSS } \quad D E T=\text { chief }=\text { EXIS } \quad \text { PREP }=\text { DET }=\text { sweatlodge }=\text { EXIS }
\end{aligned}
$$

Does it mean she talked to each chief before that chief went in? "No, that would be $i$ kukwpi7a [plural] - ti kukwpi7a means just one."

$$
\begin{aligned}
& \text { qwal'út.-s-as } \quad \mathrm{s}=\text { Mary } \quad \text { tákem } \mathrm{i}=\mathrm{kúkwpi7}=\mathrm{a} \quad \text { múta7 } \\
& \text { talk-CAUS-3ERG NOM=Mary all DET.PL }=\text { chief=EXIS and } \\
& \mathrm{i}=\text { sesq'wez' }{ }^{-}=\text {ha kéla7 } \mathrm{lh}=\text { as ulhew } \\
& \text { DET.PL }=\text { ''ger.sibling-3PL.POSS=EXIS first COMP-3CONJ enter } \\
& t i=k u ́ k w p i 7=a \quad 1=\mathrm{ti}=7 \text { ístkena } \\
& D E T=\text { chief }=\text { EXIS } \quad \text { PREP }=\text { DET }=\text { pithouse }
\end{aligned}
$$

'Mary talked to every chief and his brother before the chief went into the pithouse.'

Consultant's comment: "Only one chief went into the [pithouse]."

(41-42) illustrate the absence of donkey full DPs; see also (4) above.

$$
\begin{array}{llll}
\text { \#tákem } \mathrm{i}=\text { sqáycw=a } & \text { wa7 } & \text { s-tsúwa7 } & \mathrm{i}=\text { ts'qáx7=a } \\
\text { all } \quad \text { DET.PL=man=EXIS } & \text { IMPF } \quad \text { STAT-own } & \text { DET.PL=horse=EXIS } \\
\text { ama-s-twítas } & t i=t s \text { 'qáx7=a } & \\
\text { good-CAUS-3PL.ERG } & D E T=\text { horse }=E X I S
\end{array}
$$

Consultant's comment: "No, because it's only one horse."

\footnotetext{
${ }^{14}$ When full DPs contain pronouns, the pronouns may be bound, giving rise to apparent narrow scope/bound readings for the full DP (Kratzer's 1998 'pseudo-scope'). See Matthewson (1999) for analysis, and see (9) above for an example.
} 


$$
\begin{aligned}
& \text { *lh=wá7=as sqáxa7 ti=sqáycw=a, wa7 papt } \\
& \mathrm{COMP}=\mathrm{IMPF}=3 \mathrm{CONJ} \operatorname{dog} \quad \mathrm{DET}=\mathrm{man}=\mathrm{EXIS} \text { IMPF always } \\
& \text { tsew'-en-ás } \quad t i=s q a ́ x 7=a \\
& \text { kick-DIR-3ERG } \quad D E T=d o g=E X I S
\end{aligned}
$$

(43-44) show that using absent or plural determiners doesn't save the donkey DP.

$$
\begin{aligned}
& \text { \# tákem } \quad \mathrm{i}=\text { sqáycw=a } \quad \text { wa7 } \quad \text { s-tsúwa7 } \quad \mathrm{i}=\text { ts'qáx7=a } \\
& \text { all DET.PL }=\text { man }=\text { EXIS IMPF STAT-own DET.PL }=\text { horse=EXIS } \\
& \text { ama-s-twítas } \quad n i=t \text { s' }^{\prime} \text { áx } 7=a \\
& \text { good-CAUS-3PL.ERG DET.ABS }=\text { horse }=\text { EXIS }
\end{aligned}
$$

Consultant's comment: "No. It's still only one."

$$
\begin{array}{lllll}
\text { \# tákem } & \mathrm{i}=\text { sqáycw=a } & \text { wa7 } & \text { s-tsúwa7 } & \mathrm{i}=\text { ts'qáx7=a } \\
\text { all } & \text { DET.PL=man=EXIS IMPF } & \text { STAT-own } & \text { DET.PL=horse=EXIS } \\
\text { ama-s-twítas } & i=t^{\prime} \text { 'qáx7=a } & \\
\text { good-CAUS-3PL.ERG } & \text { DET.PL=horse=EXIS }
\end{array}
$$

'Every man who owns a horse loves the horses.'

Consultant's comment: "They love all the horses. Not just their own, but all of them."

(45) shows that full DPs cannot have E-type readings, unlike pronouns. ${ }^{15}$

$$
\begin{aligned}
& \text { (45) \# wa7 tsutánwas } \mathrm{k}=\mathrm{John} \quad \mathrm{kw}=\mathrm{s}=\mathrm{cuz} \text { kwámem } \\
& \text { IMPF think } \mathrm{DET}=\mathrm{John} \quad \mathrm{DET}=\mathrm{NOM}=\text { going.to take } \\
& \text { ku=ts'úqwaz' nílh=t'u7 xát'-min'-as } \\
& D E T=\text { fish } \quad F O C=\text { just want-RED-3ERG } \\
& \begin{array}{lll}
\mathrm{kw}=\mathrm{en}=\mathrm{cuz} & \text { q'wél-en } & t i=t s^{\prime} u^{\prime} q w a z^{\prime}=a \\
\mathrm{DET}=1 \mathrm{SG} . P O S S=\text { going.to } & \text { cook-DIR } & D E T=\text { fish }=E X I S
\end{array}
\end{aligned}
$$

'John thinks he's going to catch a fish, and he wants me to cook the fish.'

Consultant's comment: "No, because he hasn't caught it yet."

The challenge, then, is that St'át'imcets pronouns and full DPs are similar in lacking familiarity, but differ in that the full DPs lack any bound, donkey or Etype interpretations. The solution must be that the St'át'imcets overt determiners have some extra constraint which stops them having covarying interpretations.

The idea I will propose is that deictic features of the overt DPs force reference to the discourse situation, and this prevents binding or variation across situations. This will rule out both bound variable readings and all E-type

\footnotetext{
${ }^{15}$ There are a few exceptions to this, involving bridging; see below.
} 
readings. ${ }^{16}$ The idea is reminiscent of work by Wolter (2007), who claims that 'proximal demonstratives may resist opaque interpretations simply because they require the referent to be close to the speaker, which is incompatible with variation across worlds.'

The denotation for pro is repeated in (46), and the revised denotation for the singular proximal determiner is given in (47), with the deictic presupposition underlined.

$$
\begin{aligned}
& \llbracket \text { pro } \rrbracket^{\mathrm{g}, \mathrm{c}}=\lambda \mathrm{f}_{<<\mathrm{s}, \mathrm{e}>,<\mathrm{s}, \mathrm{t}>>} \cdot \lambda \mathrm{s}: \exists ! \mathrm{x} \mathrm{f}(\lambda \mathrm{s} . \mathrm{x})(\mathrm{s})=1 . \mathrm{xx} \mathrm{f}\left(\left(\lambda \mathrm{s}^{\prime} . \mathrm{x}\right)(\mathrm{s})=1\right. \\
& \llbracket t i \ldots a \rrbracket^{\mathrm{g}, \mathrm{c}}=\lambda \mathrm{f}_{<<\mathrm{s}, \mathrm{e}>,<\mathrm{s}, \mathrm{t}>>} . \lambda \mathrm{s}: \exists ! \mathrm{x} \mathrm{f}\left((\lambda \mathrm{s} . \mathrm{x})\left(\mathrm{s}_{\mathrm{o}}\right)=1 \text { where } \underline{\mathrm{s}}_{\mathrm{o}}\right. \text { is proximal to } \\
& \text { the speaker in } \mathrm{c} . \operatorname{lx~} \mathrm{f}(\mathrm{x})\left(\underline{\mathrm{s}}_{\mathrm{o}}\right)=1
\end{aligned}
$$

ti...a takes as one of its arguments an NP (e.g., smúlhats 'woman'), and presupposes that the salient proximal situation $\mathrm{s}_{0}$ contains exactly one element satisfying that NP. The entire DP denotes the unique individual which satisfies the NP in $s_{0}$. (48), for example, roughly asserts that every minimal situation $s_{1}$ containing a man and a horse he owns is part of an extended situation $\mathrm{s}_{2}$ in which the unique man in $\mathrm{s}_{2}$ loves the unique horse in the proximal situation $\mathrm{s}_{0}$.

$$
\begin{aligned}
& \text { \# tákem i=sqáycw=a wa7 s-tsúwa7 } \quad \mathrm{i}=\text { ts'qáx7=a } \\
& \text { all DET.PL }=\text { man }=\text { EXIS IMPF } \quad \text { STAT-own } \quad \text { DET.PL }=\text { horse }=\text { EXIS } \\
& \text { ama-s-twítas } \quad t i=t s^{\prime} \text { qáx } 7=a \\
& \text { good-CAUS-3PL.ERG } \quad D E T=\text { horse }=\text { EXIS }
\end{aligned}
$$

This means that every man loves a single horse which is in the vicinity of the speaker - which correctly accounts for consultants' judgments about this kind of sentence.

This analysis predicts that the individual denoted by the DP must satisfy the NP predicate in $s_{0}$. This is correct, as shown in (49-50).

Context ('The Dog Children' legend; van Eijk and Williams 1981): There is a dog who changes into a man every night, then back into a dog the next day. During the day, when he's a dog, you see him hanging around his food bowl and you say:

$$
\begin{aligned}
& \text { \#wa7 q'7-ál'men } \quad t i=s q a ́ y c w=a \\
& \text { IMPF eat-want } \quad D E T=\text { man }=E X I S \\
& \text { 'The man is hungry.' }
\end{aligned}
$$

\footnotetext{
${ }^{16} \mathrm{cf}$. a slightly different approach to a similar generalization by Gillon (2006). Gillon shows that in Skw $\underline{x} w u$ 7mesh, deictic DPs can take wide scope, while non-deictic DPs must take narrow scope. She argues that this is because deictic features prevent a DP from composing via Restrict (Chung and Ladusaw 2004).
} 
(50) Context: Same as (49), except that you saw the dog at night when he was a man and he was climbing in the window of a woman's house. You say:

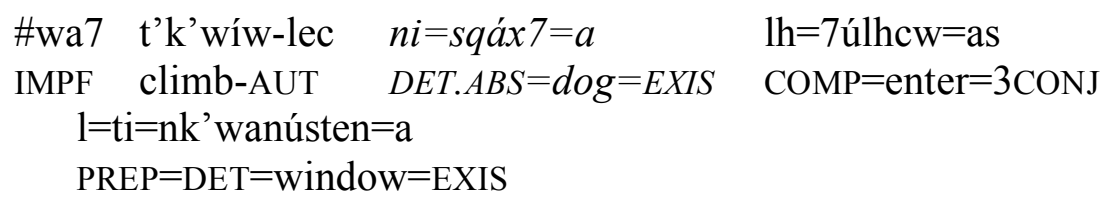

'The dog was climbing in the window.'

Consultant's comment: "No, because he was a man [when you saw him] and you have to say what you see."

The claim that a full DP in St'át'imcets always denotes an individual in the discourse situation predicts that a singular full DP should never allow a covarying interpretation, even in bridging cases. ${ }^{17}$ This prediction is largely upheld. Typical cases are shown in (51-52); the overt DP can only denote one individual (unlike in English with a definite DP).

$$
\begin{aligned}
& \text { \#papt } \mathrm{lh}=\mathrm{en} \quad \mathrm{tsicw} \quad \text { pál7alts-min } \mathrm{i}=\mathrm{ucwalmícw}=\mathrm{a} \text {, } \\
& \text { always HYP=1SG.POSS get.there visit-APPL DET.PL=person=EXIS } \\
& \text { wá7=lhkan qwal'út.-s } \quad t i=k u ́ k w p i 7=a \\
& \mathrm{IMPF}=1 \mathrm{SG} \text {.SUBJ talk-CAUS DET.PL }=\text { chief }=E X I S
\end{aligned}
$$

Consultant's comment: "Single chief."

$$
\begin{aligned}
& \text { tákem=t'u7 i=áz'=a ku=púkw pzán-itas } \\
& \text { all=just } \quad \text { DET.PL=buy=EXIS DET=book } \operatorname{meet}(\mathrm{DIR})=3 \text { PL.ERG } \\
& t i=m e t s-e n-t a ́ l i=h a \\
& \text { DET-write-DIR-TOP }=\text { EXIS }
\end{aligned}
$$

'Everyone that bought a book had met the author.'

Consultant's comment: "Same author [for everyone]."

There are a few cases where consultants accept co-varying interpretations of full DPs in bridging cases. These seem to be all instances of what Schwarz (2008) calls 'situational uniqueness'. That is, the relevant referent is always in a partwhole relation to some prior referent, rather than being e.g., the producer of a product (as in (52)). An E-type overt DP in a situational uniqueness case is given in (53). An explanation for these cases will have to wait for future research.

$$
\begin{array}{llllll}
\text { tákem } & \mathrm{i}=\mathrm{wa7} & \text { áma } & \mathrm{k}=w a & \text { tqálk'-em } & \text { wa7 } \\
\text { all } & \text { DET.PL=IMPF } & \text { good } & \text { DET=IMPF } & \text { drive-MID } & \text { IMPF }
\end{array}
$$

\footnotetext{
${ }^{17}$ Thanks to Florian Schwarz for discussion of this point.
} 
n7án'was-aka7-mín-itas ti=tqálk'-ten $=a$

two-hand-APPL-3PL.ERG $D E T=$ drive-INSTR $=E X I S$

'Everyone who drives a car well holds on to the wheel with both hands.'

In sum, I have argued that we can use Elbourne's analysis of the/it for the St'át'imcets pronouns, and appeal to the deictic features of the overt determiners to achieve the lack of bound variable, donkey, and E-type readings of full DPs. ${ }^{18}$

\section{Implications for the Analysis of Determiners and VP-Ellipsis ${ }^{19}$}

Recall that full DPs with determiners which end in $=a$ allow only referential readings. They appear to take only widest scope with respect to any scope-bearing element, as illustrated in (54).

\#tákem i=sqáyqeycw=a melyíh-s-as $\quad t i=e m h a ́ l$ 'qwem $=a$ syáqtsa 7 all DET.PL=men=EXIS marry-CAUS-3ERG DET=beautiful $=$ EXIS woman 'All the men married a beautiful woman.'

[They all marry the same one; wide-scope object]

In Matthewson $(1999,2001)$ I applied a choice function analysis to the $=a$ determiners in St'át'imcets. The choice function is existentially closed with obligatorily widest scope. That analysis correctly predicts that all non-polarity DPs take obligatory wide scope.

The problem is that as shown by Davis (2004), VP ellipsis in St'át'imcets allows sloppy readings:

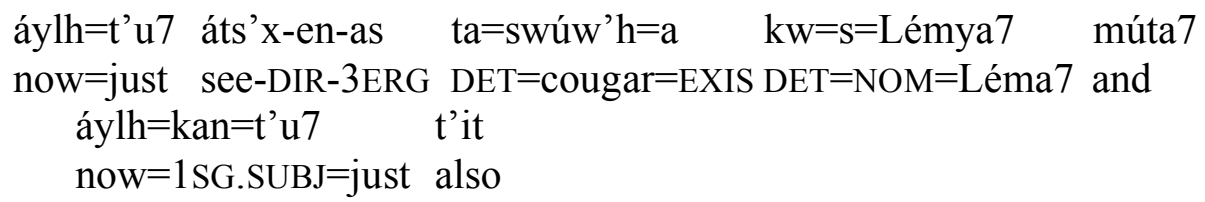

$$
\begin{array}{lll}
\text { cúz'=lhkacw }=\text { ha } & \text { ts'áqw-an' } & \text { ta=íxitsa } \\
\text { going.to=2SG.SUBJ=YNQ } & \text { eat-DIR } & \text { DET=woodworm=EXIS }
\end{array}
$$

\footnotetext{
${ }^{18}$ As mentioned in footnote 1, Roberts (2004) and others argue that English pronouns have an extra salience requirement not shared by definite descriptions. Preliminary investigations suggest a similar result in St'át'imcets, as shown in (i). This raises interesting questions about the storybeginning data presented in section 3, which I must leave for future research.

(i) kwís-ts=kan i=q'ém'p=a metsláka7, t'u7 q'em'pálmen=t'u7

fall-CAUS=1SG.SUBJ DET.PL=ten=EXIS pen but nine $=$ just

$\mathrm{i}=$ pún-an=a. t'pán'k-s=a=k'a ti=q'íl'q=a

DET.PL $=$ find-1SG.ERG $=$ EXIS under-3POSS $=$ EXIS $=$ EPIS DET $=$ chair $=$ EXIS

lh=wá7 =as lak $\quad$ xek $\quad \mathrm{ti}=$ núkw $=\mathrm{a} / \#$ pro $_{A B S}$

$\mathrm{HYP}=\mathrm{IMPF}=3 \mathrm{CONJ}$ lie maybe $\mathrm{DET}=$ other $=\mathrm{EXIS} /$ \# $\mathrm{pr}_{A B S}$

'I dropped 10 pens and only found 9 of them. The other one /\#it is probably under the chair.'

${ }^{19}$ Material in this section relies on Davis and Matthewson (2008).
} 


$$
\begin{array}{ll}
{\left[1 \mathrm{~h}=\mathrm{cú}^{\prime}=\right.\text { an }} & \text { kéla7 }] \\
{[\mathrm{COMP}=\text { going.to=1SG.CONJ }} & \text { first }]
\end{array}
$$

(Davis 2004)

'Will you eat a woodworm if I do first?' [can be a different woodworm]

If we copy the VP, and existentially close the choice function with widest scope, we derive only the strict reading. In (56), we must see the same cougar.

$$
\exists f[[\lambda x \text {. x saw } f(\text { cougar })](\text { Lémya } 7) \&[\lambda x \text {. x saw f(cougar })](I)]
$$

The only way to derive a sloppy reading is to have two different choice functions, one for the overt DP and one for the elided one, as in (57):

$$
\exists f \exists g[[\lambda x \text {. x saw f(cougar) }](\text { Lémya } 7) \&[\lambda x \text {. x saw g(cougar) }](I)]
$$

But this violates parallelism constraints on VP ellipsis: randomly changing variables in the elided VP is not allowed (Fiengo and May 1994).

However, the analysis I have argued for above solves this problem. Recall that pronouns in St'át'imcets can function as bound variables, while full DPs cannot. I derived this contrast from the idea that the overt determiners contain deictic features. The sloppy identity facts now show that elided DPs parallel pronouns in their ability to function as bound variables. The generalization therefore is that whenever the determiner is not pronounced, bound variable anaphora is possible. All we have to assume, then, is that when a determiner is elided, it loses its deictic features. Its denotation reduces to that of a pronoun, and sloppy identity is predicted in the same way as Elbourne's analysis of English pronouns/determiners predicts sloppy identity.

There is independent evidence that deictic features are lost under ellipsis, coming from VP-ellipsis cases where the required deictic properties of the overt DP and the elided DP differ, yet the identity condition on ellipsis is clearly satisfied. This is shown in (58), which would be bad with an overt absent determiner on 'Bill's grandmother'.

(58) Context: John's grandmother is dead [i.e., absent], Bill's grandmother is still alive and is sitting with us in the room [i.e., present].

$$
\begin{aligned}
& \text { stexw wa7 xwey-s-ás } n a=\text { kwékwa7-s=a } \\
& \text { very IMPF love-CAUS-3ERG DET.ABS=grandmother-3POSS=EXIS } \\
& \mathrm{s}=\mathrm{John}, \quad \text { stexw t'it } \mathrm{s}=\text { Bill } \\
& \mathrm{NOM}=\text { John very also } \mathrm{NOM}=\text { Bill } \\
& \text { 'John really loves his grandmother, and so does Bill.' [sloppy ok] }
\end{aligned}
$$

\section{Conclusions}

In this paper I have argued that the semantics of third-person pronouns is crosslinguistically variable, but in at least two languages, the pronouns share basic 
semantics with determiners in the relevant language. I have claimed that languages vary in the discourse effects of their presuppositions, and this can affect determiners and third-person pronouns as well as other presupposition triggers. I have argued that determiners may have extra deictic features which prevent binding, and that a situation semantics analysis captures all the facts about St'át'imcets determiners more successfully than the prior choice function analysis.

\section{References}

Abbott, Barbara: 1999, 'Support for a Unique Theory of Definite Descriptions', Proceedings of SALT IX, CLC Publications, Cornell University, Ithaca, 114.

Abbott, Barbara: 2003, 'A Reply to Szabo's 'Descriptions and Uniqueness', Philosophical Studies 113:223-231.

Abbott, Barbara: 2005, 'Issues in the Semantics and Pragmatics of Definite Descriptions in English', To appear in J. Gundel and N. Hedberg (eds.), Interdisciplinary Perspectives on Reference Processing.

Abusch, Dorit: 2005, Triggering From Alternative Sets and Projection of Pragmatic Presuppositions', Ms., Cornell University.

Beaver, David: 2001, Presupposition and Assertion in Dynamic Semantics, CSLI Publications, Stanford University.

Berman, Stephen: 1987, 'Situation-Based Semantics for Adverbs of Quantification', in J. Blevins and A. Vainikka (eds.), Studies in Semantics, UMOPL, GLSA, Amherst, 46-68.

Birner, Betty and Gregory Ward: 1994, 'Uniqueness, Familiarity, and the Definite Article in English, BLS 20:93-102.

Chung, Sandra and William A. Ladusaw: 2004, Restriction and Saturation, MIT Press, Cambridge, MA.

Chung, Sandra, William A. Ladusaw and James McCloskey: 1994, 'Sluicing and Logical Form', Natural Language Semantics 3:239-282.

Davis, Henry: 2000a, 'Coordination and Constituency in St'át'imcets', Papers for the 35th ICSNL, UBCWPL, Vancouver, 49-78.

Davis, Henry: 2000b, 'Remarks on Proto-Salish Subject Inflection', International Journal of American Linguistics 66: 499-520.

Davis, Henry: 2003, 'Mind the Gap: On Plural Agreement and A'-Extraction in St'át'imcets (Lillooet Salish)', Papers for the 38th ICSNL, UBCWPL, Vancouver, 23-45.

Davis, Henry: 2004, 'VP Ellipsis in St'át'imcets and Some of its Implications', Papers for the 39th ICSNL, UBCWPL, Vancouver, 117-140.

Davis, Henry: 2006, 'The Status of Condition C in St'át'imcets', in S. Bischoff, L. Butler, P. Norquest and D. Siddiqi (eds.), MIT Working Papers in Endangered Languages: Studies in Salishan, 49-92.

Davis, Henry and Lisa Matthewson: 2008, 'VP-Ellipsis and (the Absence of) Choice Functions in St'át'imcets', Poster presented at the Canadian 
Linguistics Association, University of British Columbia.

Davis, Henry, Ryan Waldie and Rachel Wojdak: 2007, 'Condition C in Nuuchah-nulth', Canadian Journal of Linguistics 52: 185-222.

van Eijk, Jan: 1997, The Lillooet Language: Phonology, Morphology, Syntax, UBC Press, Vancouver.

van Eijk, Jan and Lorna Williams: 1981, Cúystwi Malh Ucwalmícwts, Ts'zil Publishing House, Mount Currie.

Elbourne, Paul: 2001, 'E-type Anaphora as NP-Deletion', Natural Language Semantics 9:241-288.

Elbourne, Paul: 2005, Situations and Individuals. MIT Press, Cambridge, MA.

Fiengo, Robert and Robert May: 1994, Indices and Identity, MIT Press, Cambridge, MA.

von Fintel, Kai: 1994, Restrictions on Quantifier Domains. Doctoral dissertation, University of Massachusetts, Amherst.

von Fintel, Kai: 2000, 'What is Presupposition Accommodation?', Ms., MIT. von Fintel, Kai: 2004, 'Would You Believe It? The King of France is Back! Presuppositions and Truth Value Intuitions', in Reimer and Bezuidenhout (2004), 269-296.

Gauker, Christopher: 1998, 'What is a Context of Utterance? Philosophical Studies 91:149-172.

Gillon, Carrie: 2006, The Semantics of Determiners: Domain Restriction in Skwxwú7mesh, Doctoral dissertation, University of British Columbia.

Hawkins, John: 1991, 'On (In)definite Articles: Implicatures and (Un)grammaticality Prediction, Journal of Linguistics 27:405-442.

Heim, Irene: 1982, The Semantics of Definite and Indefinite Noun Phrases. Doctoral Dissertation, University of Massachusetts, Amherst. Published 1987, Garland Press, New York.

Heim, Irene: 1990, 'E-Type Pronouns and Donkey Anaphora', Linguistics and Philosophy 13:137-177.

Kadmon, Nirit: 1987, On Unique and Non-Unique Reference and Asymmetric Quantification, Doctoral Dissertation, University of Massachusetts, Amherst. Published 1992, Garland Press, New York.

Kamp, Hans: 1981, 'A Theory of Truth and Semantic Representation', in J. Groenendijk, T. Janssen and M. Stokhof (eds.) Formal Methods in the Study of Language, Mathematical Centre Tract 135, Amsterdam, 277-322.

Kratzer, Angelika: 1998, 'Scope or Pseudo-Scope? Are There Wide-Scope Indefinites?', in S. Rothstein (ed.), Events in Grammar, Kluwer, Dordrecht.

Ludlow, Peter and Gabriel Segal: 2002, 'On a Unitary Semantical Analysis for Definite and Indefinite Descriptions', in Reimer and Bezuidenhout (2004), 420-436.

Matthewson, Lisa: 1998, Determiner Systems and Quantificational Strategies: Evidence from Salish, Holland Academic Graphics, The Hague.

Matthewson, Lisa: 1999, 'On the Interpretation of Wide-Scope Indefinites', Natural Language Semantics 7:79-134. 
Matthewson, Lisa: 2001, 'Quantification and the Nature of Cross-Linguistic Variation', Natural Language Semantics 9:145-189.

Matthewson, Lisa: 2005, When I Was Small - I Wan Kwikws: Grammatical Analysis of St'át'imcets Oral Narratives, UBC Press, Vancouver.

Matthewson, Lisa: 2006, 'Presuppositions and Cross-Linguistic Variation', Proceedings of the North East Linguistics Society 36, GLSA, Amherst.

Matthewson, Lisa: in press, 'An Unfamiliar Proportional Quantifier', in A. Giannakidou and M. Rathert (eds.), Quantification, Definiteness, and Nominalization, Oxford University Press, Oxford.

Postal, Paul: 1966, 'On So-Called "Pronouns" in English', in F. Dinneen (ed.), Report on the Seventeenth Annual Round Table Meeting on Linguistics and Languages Studies, Georgetown University Press, Washington, DC, 177-206.

Reimer, Marga and Anne Bezuidenhout (eds.): 2004, Descriptions and Beyond, Oxford University Press, Oxford.

Roberts, Craige: 2004, 'Pronouns as Definites', in Reimer and Bezuidenhout (2004), 503-543.

Roberts, Taylor: 1999, 'Grammatical Relations and Ergativity in St'át'imcets', International Journal of American Linguistics 65: 275-302.

Sauerland, Uli: 2000, 'The Content of Pronouns: Evidence From Focus', Proceedings of SALT X, CLC Publications, Cornell University, Ithaca, 167-184.

Schlenker, Philippe: 2008a, 'Be Articulate! A Pragmatic Theory of Presupposition Projection', to appear in Theoretical Linguistics.

Schlenker, Philippe: 2008b, 'Presupposition Projection: The New Debate', paper presented at SALT XVIII, University of Massachusetts, Amherst.

Schwarz, Florian: 2008, 'Two Types of Bridging With Two Types of Definites', paper presented at Stanford University.

Simons, Mandy: 2001, 'On the Conversational Basis of Some Presuppositions', Proceedings of SALT XI, CLC Publications, Ithaca.

Simons, Mandy: 2006a, 'Foundational Issues in Presupposition', Philosophy Compass 1:357-372.

Simons, Mandy: 2006b, 'Presupposition Without Common Ground', Ms., Carnegie Mellon University.

Szabo, Zoltan: 2000, 'Descriptions and Uniqueness', Philosophical Studies 101:29-57.

Szabo, Zoltan: 2003, 'Definite Descriptions Without Uniqueness: A Reply to Abbott', Philosophical Studies 114:279-291.

Thoma, Sonja: to appear, 'Ti Lhápa Ts'úqwaz' Láti7 Q'íl'qa: The Forgotten Fish on the Sofa', in L. Matthewson, C. Christodolou and M. Oberg (eds.), Wenácw Ti7: True Stories by a St'át'imc Elder, UBCWPL, Vancouver.

Tomioka, Satoshi: 2003, 'The Semantics of Japanese Null Pronouns and its Semantic Implications', in K. Schwabe and S. Winkler (eds.), Interfaces: Deriving and Interpreting Omitted Structures, John Benjamins, Oxford, 321-340.

Wolter, Lynsey: 2007, 'Situation Variables and Licensing by Modification in Opaque Contexts', Proceedings of Sinn und Bedeutung 11. 